\title{
Interdisciplinary Connections through Transmedia Narratives in Art Education
}

BEA ToMšič $\mathrm{AMON}^{1}$

$\approx$ The world of new media has inevitably changed teachers' and students' attitude towards information. Data of all kinds and from any scientific field are easily available at any time. Nevertheless, isolated data have nothing to do with knowledge. We refer to »knowledge « when an interdependence of information has a particular significance in defined conditions. How to use and connect this information is one of the primary issues teachers have to engage with since they are still the main organisers of the educational process. Taking into account the objectives of his/her explanations, he/she chooses certain relevant contents, and connects them, striving for an interdisciplinary view of the world that makes sense and gives sense to his/ her explanations, all in an attempt to motivate students in their approach to knowledge. This article presents research in which the participants, future art teachers, had to answer a questionnaire that required comparing artistic compositions and compositions present in nature. Almost half of them could not find proper examples, even though the participants were students who should have been able to manage contents from both fields. Understanding how art follows nature is an important goal within the education of future art teachers. Difficulty in connecting data, transferring knowledge, giving meaning to images and understanding visual and verbal discourse seem to be a persistent problem in many aspects of their education. Possible strategies to improve the situation using transmedia narratives are presented in the conclusion.

Keywords: art and nature, art education, interdisciplinary connections, teachers' education, transmedia narratives

1 Faculty of Education, University of Ljubljana, Slovenia; beatriz.tomsic@pef.uni-lj.si. 


\section{Interdisciplinarne povezave s transmedijskimi pripovedmi pri umetniški vzgoji in izobraževanju}

BEA ToMšič AMON

$\propto$ Svet novih medijev je neizogibno spremenil odnos učiteljev in študentov do informacij. Podatki vseh vrst in s katerega koli znanstvenega področja so lahko dostopni kadar koli. Kljub temu izolirani podatki nimajo nič skupnega z znanjem. Na znanje se sklicujemo, kadar soodvisnost informacij v določenih pogojih dobi poseben pomen. Kako uporabljati in povezati informacije, je eno glavnih vprašanj, ki si ga morajo učitelji postaviti, saj so še vedno glavni organizatorji izobraževalnega procesa. Ob upoštevanju ciljev svojih razlag učitelj izbere ustrezne vsebine in jih poveže med seboj v prizadevanju za interdisciplinarni pogled na svet, ki je smiseln in ustrezen za njegova pojasnila. Tako poskuša motivirati študente za poglabljanje znanja. Ta članek predstavlja raziskavo, v kateri so morali udeleženci, prihodnji učitelji likovne umetnosti, odgovoriti na vprašalnik, ki je zahteval primerjavo umetniških kompozicij in kompozicij, ki so prisotne v svetu narave. Skoraj polovica jih ni našla ustreznih primerov, čeprav so bili udeleženci študentje, ki bi morali obvladovati vsebine $\mathrm{z}$ obeh področij. Razumevanje, kako umetnost sledi naravi, je pomemben cilj pri izobraževanju prihodnjih učiteljev umetnosti. Težave pri povezovanju podatkov in prenosu znanja, sposobnost osmišljanja slikovnega gradiva ter razumevanja vizualnega in besednega diskurza se zdijo redno prisotne težave $\mathrm{v}$ veliko pogledih $\mathrm{v}$ njihovi izobrazbi. V sklepnem delu so predstavljene mogoče strategije za izboljšanje stanja s pomočjo transmedijskih pripovedi.

Ključne besede: umetnost in narava, likovna vzgoja, interdisciplinarne povezave, izobraževanje učiteljev, transmedijske pripovedi 


\section{Introduction}

\section{On Knowledge}

The world of new media has inevitably changed teachers' and students' attitude towards information. Data of all kinds and from any scientific field are easily available at any time.

Nevertheless, isolated data have nothing to do with knowledge. We could refer to »knowledge« when an interdependence of information has a particular significance in defined conditions. It is a concept that is difficult to define from only one point of view because it can hold different meanings, depending on the context. Many authors question the idea that all scientifically produced knowledge is true in all places and for all times (e.g., Gray, 2000; Kincheloe, 2008; Shannon \& Galle, 2016).

Kincheloe (2008) opens relevant questions in order to reflect on the role of the teacher in the production and spread of knowledge:

Are teachers merely managers of the predetermined knowledge of dominant cultural power? Is teacher education merely the process of developing the most efficient ways for educators to perform this task? Do teachers operate as functionaries who simply do what they are told? (p. 9)

These questions are not separated from the most fundamental features of teaching and learning.

Gray (2000) thinks that:

[...] a considerable body of literature addresses the management of knowledge from a variety of perspectives: the use of information systems, social networks, communities of practice work processes and other forms of organisational practices as methods for managing the creation and/or transmission of relatively unstructured knowledge. A separate research tradition examines the use of structured knowledge representations embedded in technology to enhance decision making including considerable research into methods and tools for knowledge acquisition. Some knowledge management practices are relatively new while others have long histories. (p. 2)

Regardless, the process of teaching and learning, dealing with the »circulation " of knowledge, is not operated in a single direction and only by the teacher. More often than not, the teacher is a screenwriter creating stories, accounts of a series of related events, experiences which through argumentation, description, exposition, and similar are part of the rhetorical modes of discourse he/she uses 
to motivate students in their approach to knowledge. Taking into account the objectives of his/her explanations, he/she chooses certain relevant contents, connects them, striving for an interdisciplinary view of the world that makes sense and gives sense to his/her narration (Seely Brown \& Duguid, 2000).

\section{On Interdisciplinarity}

Moss et al. (2008) define interdisciplinarity as:

[...] the synthesis of two or more disciplines such that a new level of discourse and assimilation of knowledge is achieved. In practice, the process of interdisciplinary instruction often begins with a topic, theme, problem, or project that requires active student participation and knowledge of multiple disciplines in order to reach a resolution. (p. 72)

The emphasis is on becoming more knowledgeable about a variety of disciplines, making connections within and among disciplines, seeing problems from multiple perspectives, appreciating diversity, and developing an ability to solve complex problems.

Moss et al. (2008) state that

The traditional school disciplines divide knowledge into organised and helpful hierarchies of skills, concepts, procedures, theories, and ways of knowing that bring order to our understanding and structure to our schools. At the same time, the discipline-defined model of curriculum and instruction may prevent students from developing the interdisciplinary perspective required to tackle complex, real-world problems that are rarely aligned with individual disciplines. (p. 73)

As evidenced by Meier et al. (1996), students taught within the lecturebased disciplinary system typically are not able to solve problems that require them to make connections and use relationships between concepts and content.

In most definitions, an interdisciplinary approach means the achievement of certain skills, knowledge and competencies that are shared by different school subjects or disciplines. An integrated interdisciplinary approach deals with concepts that are common to various study areas. It means a meta-curricular approach to the development of mental abilities, social skills, multiple intelligences, technology and learning abilities through different disciplines due to their intrinsic transfer values.

Pedagogical strategies based on interdisciplinary approaches are centred on the fact that integration activates a process derived from explicit learning objectives, conceptual, learning-targeted and development planning (Moss et al., 2008). 
According to Tomšič Amon (2020):

The ideological assumptions that form the basis of our school system point to the advantage of subjects that express logical-analytical-mathematical thinking and the ability of verbal expression while artistic-aesthetic experience and expression are pushed into the background. The system clearly gives priority to the development and use of the left brain hemisphere. The recognition that both hemispheres do not function separately, but effectively complement their functions leads to the conclusion that priority should be given to such processes that integrate the ability of both brain cells. Gardner's (1993) multiple intelligence theory, which is in general very well known for at least a couple of decades, distinguishes linguistic, musical, logical-mathematical, spatial, motor, interpersonal and intrapersonal intelligence, supports crosscurricular integration. Children should be able to develop all seven intelligences, as this is the only way to discover and exploit their potentials. (p. 54)

Teaching with or through visual art reveals its interdisciplinary nature. Any other school subjects can be taught in a way that is art-based. Consequently, some crucial questions emerge: How can other subjects benefit from visual art education? What contingencies can be expected from an unsuitable application of interdisciplinary pedagogic strategies for visual art itself? How can specific strategies or methods of visual art (e.g., visualisations, representations, etc.) assist other areas of knowledge? We will not respond to these questions here, but attempt to offer approximate approaches with elements that could indicate a route to the answers.

\section{Transmedia narratives}

Transmedia storytelling, also known as transmedia narrative or multiplatform storytelling, is the technique of telling a single story or story experience across multiple platforms and formats using current digital technologies. Transmedia narratives eventually mean using multiple forms of media that deliver unique content through different channels (Jenkins, 2006).

Transmedia narratives traditionally refer to allowing audience participation, such that each successive platform heightens the audience's enjoyment. Pratten (2015, p. 17) completed this definition, stating that »this means taking the audience on an emotional journey that goes from moment-to-moment «. Even if these experiences are difficult to assess, control, and evaluate, the results showed this to be a suitable strategy in the educational process.

The technical means that are today accessible to teachers have changed the nature of their narratives in the context of the teaching/learning process. The stories 
that once could be presented only in a textual or audio-visual form, today can be created using a much wider range of possibilities, addressing all the senses, immersing the viewer in a much more convincing new reality and requiring no specific conditions to become effective. However, narrations are always directed to a certain audience because they are an act of communication. In this process, the storyteller is practically as important as the public. An effective narrative points out not only the storytellers' perceptions but also the perceptions of the spectators: the teacher and the students (Kalinov, 2017). »Transmedia storytelling mimics daily life, making it a strong constructivist pedagogical tool for educational uses« (Wilson, 2004, p. 106).

Multi sensorial experiences should unfold the potentialities of cognitive, affective and psychomotor development of the students. In these cases, we can assert that these narratives are transmedia narratives essential in creating an actual community of knowledge (Jenkins, 2010).

Through transmedia approaches, concepts can be presented as different aspects of reality. These concepts enable the transfer of thinking strategies and enhance critical thinking. The promotion of higher levels of mental skills can be intensified through the creative solving of problems within different subjects (Erickson, 1995), which means that a comprehensible conceptual structure stands behind a pedagogic model that assumes that critical thinking capabilities and other abilities need to be developed to achieve desired results.

Contents and learning processes are always intertwined and depend one on the other. Drake (1998) agrees with this view, as he says that holistic information can be easily and quickly recalled in memory as the brain is organised to receive more information simultaneously.

In contrast, Arnheim (1993) insists on the relations between perception and concept formation, stating that:

[...] to simplify the complex process of concept formation, I will say that as optic images become specific, the mind processes the accumulated sensorial material in a very sophisticated way. It identifies the persistent objects and recognises them every time it meets them in an experience [...] to be able to discover the structures that lay under any object, it is necessary to refine visual and analytical skills because the fundamentals of visual concept formation are the optic images. (p. 31)

In a more general scope, but with a similar message Catmull (2014) says that if we do not strive to uncover what is unseen and understand its nature, we will be ill-prepared to lead.

Perception linked to close observation is conditioned by certain important factors, such as attention, linked to emotions, memory, previous experiences, 
personal affinities to visual or auditory search, and the individual capacity to rationalise mainly emotional processes that give shape to one's capacities of encoding and decoding signs in the environment (Wright \& Ward, 2008).

Perceptions in an overly full environment, where it is difficult to distinguish elemental phenomena of the circumstantial, where stimuli kindle all around us, are miscellaneous experiences that teachers and students bring to the class. Perceptions can limit our emotions, and attention or on the contrary motivate a rich process becoming aware of the world in a particular way.

In contrast, Crary (1992) affirms:

[...] that the more the senses are revealed to be inconsistent, conditioned by the body, prey to the thread of distraction and no productivity, the more a normative individual is defined in terms of objective and statistical attentional capacities that facilitate the subject's functional compatibility within institutional and technological environments. (p. 72)

These suppositions are of crucial importance within the educational process.

The learning process is affected by the process resulting from perception as a current action. The use of the experience of the senses and the detection of information using mental or visual conceptualisation are the main elements that allow students to process information. Reflecting on how to address individual students' learning needs means planning meaningful classroom experiences that improve the process of retaining the learnt information.

\section{Visual Narratives}

The diversity of current society requires of each individual the development of creativity - such an irreplaceable factor - in the different aspects of life. Art education helps develop not only artistic creativity but creativity in general. That is why it is an important segment of the educational process.

Artistic creativity is a complex that includes ability in the use of materials and tools, procedures and working methods, sensitivity in the perception of art products and their material qualities, flexibility in the transformation of materials and the solution of artistic problems. That is why the encouragement of artistic creativity is fundamental in the development of the learners' personalities. Linking logic and artistic subjects through interdisciplinary planning at school helps students think how to solve actual analytical problems in different or even, at first sight, contradictory fields, such as sciences and art.

Eisner (2002) reminds us that a wider approach to knowledge is needed, stating that art can make vivid what words and numbers taken literally, exhaust much earlier. 
The majority of students nowadays are in daily contact with digital media, manage different computer software, printers and scanners, and know how to manipulate images, but actual mastery in these complex world of possibilities is not entirely common. The photo camera has spread far and wide and has become a powerful instrument in the creation of images. However, despite its popularity, it has not taken the viewers to a higher level of seeing.

Today, everyone can take pictures, shoot a video, and share it on digital social media, but there is a significant difference between randomly capturing daily life, and creating visuals to tell visual stories. Visually interesting content and discussions are at the foundation of visual storytelling. Kroeber (2006) describes the precise differences between the psychological experience of reading a novel and watching a movie and the relation of private experience to the natural environment. Lankow et al. (2012) show the vast potential in using the communication medium as a marketing tool by creating informative and shareable infographic content. These are only two examples of the fields in which transmedia narratives have become extremely popular.

Apart from the conceptual aspects, the proliferation of devices is a major challenge that students face within art education. The ability to see and evaluate images with a well-educated eye is crucial; this is of key importance in the art education teaching and learning process - it is one of its main goals.

This article presents research in which we attempted to evaluate the possibilities transmedia narratives offer to improve the quality of the pedagogical process within interdisciplinary connections.

\section{Method}

The research was carried out during the 2018/19 school year. It included 71 students finishing the undergraduate degree of Primary Education Teachers study programme. After the one-year master degree graduation, they would teach fine arts from the $1^{\text {st }}$ to the $5^{\text {th }}$ grade of primary school, as well as natural sciences and mathematics. A primary teacher (i.e., one who teaches all the school subjects from $1^{\text {st }}$ to $5^{\text {th }}$ grade), a biology teacher, and a mathematics teacher also participated as consultants.

The idea for the research came about after we noticed that even though exercises comparing artistic compositions and the compositions present in the world of nature and geometry performed in the class were many times, surprisingly within the final examination, students answering the question were not as successful as expected. Forty-nine per cent of the students did not answer the following question properly: »Find an example of a geometric composition in nature and a similar 
example in the field of fine arts and describe them by comparison (with the visual material of your choice) «. An example of the visual material that was expected from the students as an answer to the question is presented in Figure 1.

\section{Figure 1}

Example of the visual material that was expected from the students: the geometric composition of a flower around a pentagon and a similar composition in art. In this case, Michelangelo's Doni Tondo, tempera on panel, 1506
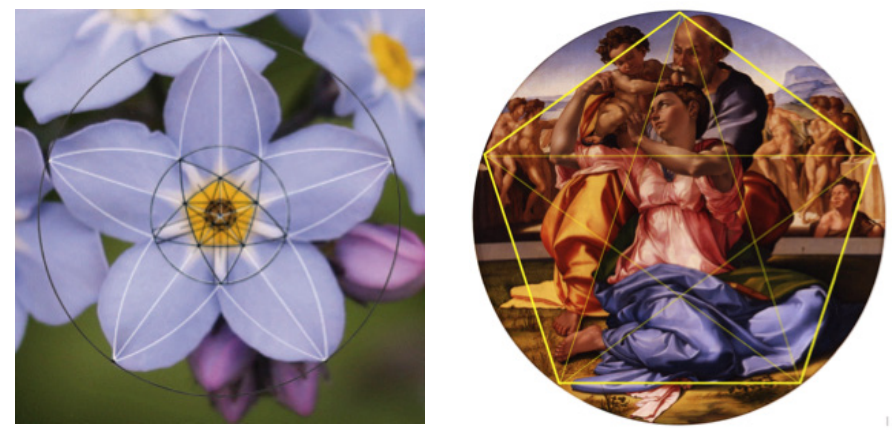

Dissatisfied with the results within the final examination, we had to accept that probably it is not possible to expect interdisciplinary visual connections if students had not developed these specific competencies in a proper way before and under their teacher's guidance. The question that arose was which teaching and learning strategies may promote the development of these competencies as a transfer between different areas of study, specifically the transfer of visual experiences and knowledge from other subjects?

The research resulted in an action research study with three phases. Within each phase, we tested a specific strategy, attempting to upgrade students' experiences from the previous phase. As Thomas (2019) states:

Qualitative methods were selected because they are regarded as valid and reliable ways of documenting and interpreting the subtlety of social transactions and were well suited to observing at close range the inherently collective and transactional character of the creative classroom«. (p. 4)

In the first phase of the research, students had to find and analyse the graphic material themselves. The task was to find an example of a geometric composition in nature and a similar example in the field of fine arts and describe them by comparison (with the visual material of the students' choice, as in Figure 1) which in many cases proved to be quite problematic. Many of the students stated that it was a difficult task that they had never done anything like it before. 
That is why, in the second phase, we decided to prepare a test. It consisted of six similar tasks. This time all the graphic material was given. The geometric elements were presented in a logical order (i.e., line, triangle, square, pentagon, hexagon, and a circle) while the photos from the natural world, flowers, animals and the reproductions of the paintings were given in no particular order (Critchlow, 2011). The task was to link the three examples that had common characteristics with a line.

In this case, the test results were analysed as follows: within each of the rubrics Nature and Fine Arts, we established how many answers were correct. There was a special rubric for the cases that were correct in both rubrics. The results of the test are in Table 1.

Table 1

Results of the test realised within the second phase of the research

\begin{tabular}{|c|c|c|c|c|c|c|c|c|c|c|}
\hline \multirow{3}{*}{ GEOMETRY } & \multicolumn{4}{|c|}{ NATURE } & \multicolumn{4}{|c|}{ FINE ARTS } & \multirow{2}{*}{\multicolumn{2}{|c|}{$\begin{array}{l}\text { COINCIDENCE } \\
\text { Nature/Fine art }\end{array}$}} \\
\hline & \multicolumn{2}{|c|}{ Correct } & \multicolumn{2}{|c|}{ Incorrect } & \multicolumn{2}{|c|}{ Correct } & \multicolumn{2}{|c|}{ Incorrect } & & \\
\hline & $f$ & $\%$ & $f$ & $\%$ & $f$ & $\%$ & $f$ & $\%$ & $f$ & $\%$ \\
\hline & 64 & 90.14 & 7 & 9.86 & 71 & 100 & 0 & 0 & 64 & 90.14 \\
\hline & 71 & 100 & 0 & 0 & 71 & 100 & 0 & 0 & 71 & 100 \\
\hline & 65 & 91.55 & 6 & 8.45 & 25 & 35.21 & 46 & 64.79 & 22 & 30.99 \\
\hline & 65 & 91.55 & 6 & 8.45 & 22 & 30.99 & 49 & 69.01 & 20 & 28.17 \\
\hline & 68 & 95.77 & 3 & 4.23 & 9 & 12.67 & 62 & 87.33 & 5 & 7.04 \\
\hline & 71 & 100 & 0 & 0 & 71 & 100 & 0 & 0 & 71 & 100 \\
\hline
\end{tabular}


Although these tasks were easier to understand, there are some interesting points when observing the differences among the six examples. The results for the line, triangle and circle were excellent; in the three cases, there was a high coincidence between Nature and Fine Arts (line: 90.14\%, triangle: $100 \%$, and circle: $100 \%)$. The square got good marks in Nature (91.55\%) and poor in Fine Arts (35.21\%). A similar situation happened with the pentagon (Nature: 91.55\%, Fine Arts: $30.99 \%$ ). In these two cases, the coincidence was of $29.58 \%$ on average. The hexagon presented different results because the majority $(87.33 \%)$ had difficulties discovering the hexagonal schema in the composition of the painting. Following this, the coincidences are low (7.04\%).

We were still not satisfied with the results. In discussion with the consultant teachers, we confirmed that many students simply could not see the geometrical structure of compositions, neither in nature nor in art. Probably these students perceive contents from different subjects as entirely separated from a core structure of knowledge of which they are part. We had to improve research to determine strategies that would show efficient when interdisciplinary contents were our object.

Following these ideas, a new strategy had to be implemented in the third phase of the research. Teaching and learning experiences become an interconnected complex, stimulating multi-layered sensitive, emotional reactions because students need to develop tools for precise observation, interpretation, negotiation, and meaning-making of the information to which they are exposed. They need to be provided tools that should (in the future) help them make precise interpretations of information. Unconnected information does not mean much if it is displayed in a context that keeps out a holistic representation of the world; this was one of the conclusions we arrived at after the second phase of the research.

How to facilitate the tools students need in a world of endless possibilities of getting information is a query addressed to the teachers. Selecting, decoding, and making meaning from them is a process that primarily engages emotions and attention. Emotions lead to attention; thus, they are an important internal motivation tool in the teaching/learning process (Vimal, 2019; Wright \& Ward, 2008). Attention stresses the potentials of multisensory emotional arousal, which increases memory consolidation, the process of creating a permanent record of the encoded information, and allows for different interpretations, negotiation, and meaning-making of them (Yiend, 2010). Teaching and learning are impossible if there is a lack of motivation between the students and the teacher.

To improve motivation among the students, we decided that probably the use of new media should provide us with a new possibility to approach the 
problem of how to design a more efficient interdisciplinary pedagogical process show. The strategy now was to use transmedia narratives and work in groups. Transmedia narratives, as stated before, use multiple forms of media that deliver unique content through different channels (Jenkins, 2006). Even if these experiences are difficult to assess, control, and evaluate, the results showed this is a suitable strategy in the educational process.

Facebook, Instagram, YouTube, and other platforms in digital media give space to new forms of dialogue among their users, as any material can be easily shared in them. We do not know anything about the destiny of any material we share in such media and the reactions it can produce. Many specific and unpredictable stories can be created out of the departing point that any posted material is.

One of the main goals of the third phase of the research was to verify to what extent students would go deep in their acquisition of knowledge through an experience that did not present any limitations regarding learning contents. Another goal was to detect how would students take advantage of the proposal to use different distribution channels during their learning process.

Transmedia strategies present the advantage that educators can create projects that students can begin to develop in classroom settings, and then venture out into the community to complete them, taking control of their learning by becoming actively engaged participants (Shannon \& Galle, 2016, p. 38) or, as Wurdinger suggests, »they are more challenging to implement than other approaches because they require spending some time away from the college classroom « (in Shannon \& Galle, 2017, p. 51).

We decided to launch the third phase of our research, including three basic parts that considered key activities. The first part included the formation of working groups among students, the presentation of the basic contents by the teacher, the distribution of the themes between the groups of students and the realisation of an introductory art work. It also included individual gathering of information, elaboration, and presentation using multimedia to the rest of the participants in each group. The second phase was meant for the students' interchange in social media, creating a story from the collected information within the groups. The visual stories students created linking the information required the elaboration of ideas and planning solutions, originality, which meant unusual strategies when solving the problem of presenting the results using multimedia. Interchange in social media, creating a story from the collected information, from different viewpoints, was a part of the challenge. In the end, they all had to upload their works in a newly created group that included the whole of the cohort. 
The third part included interchange and connection of different viewpoints' stories. The short and essential story of understanding the meanings and scope of the contents should lead to a new original and wider visual story. At the end of this part, students from each group had to propose an activity within art education intended for the students that participated in the rest of the groups. Some activities were very interesting and a very creative way to show how the interdisciplinary knowledge grew through all the pedagogical process. Figure 2 shows two examples of works based either on an example from nature or of the world of Fine arts and became a new object, the design of a pattern for textiles. What is interesting is that the original designs were linked to the shape of the pentagon and the hexagon; "playing « with the shapes made them discover the square in their patterns and develop their knowledge and competencies to link contents that have complementary meanings. This was the conclusion of students' activities and was meant to use and consolidate the acquired knowledge practically. The last part of the project included a meeting of all the participants, where students presented the development of their work during the different phases. This was the material assessed by the teachers. In this way, we could have a picture of the process within all the groups of students, compare the results, and draw conclusions.

\section{Figure 2}

Two examples of works based either on an example from nature or of the world of Fine arts and became a new object, the design of a pattern for textiles. From Victor Vasarely, Geometric forms, 1948.
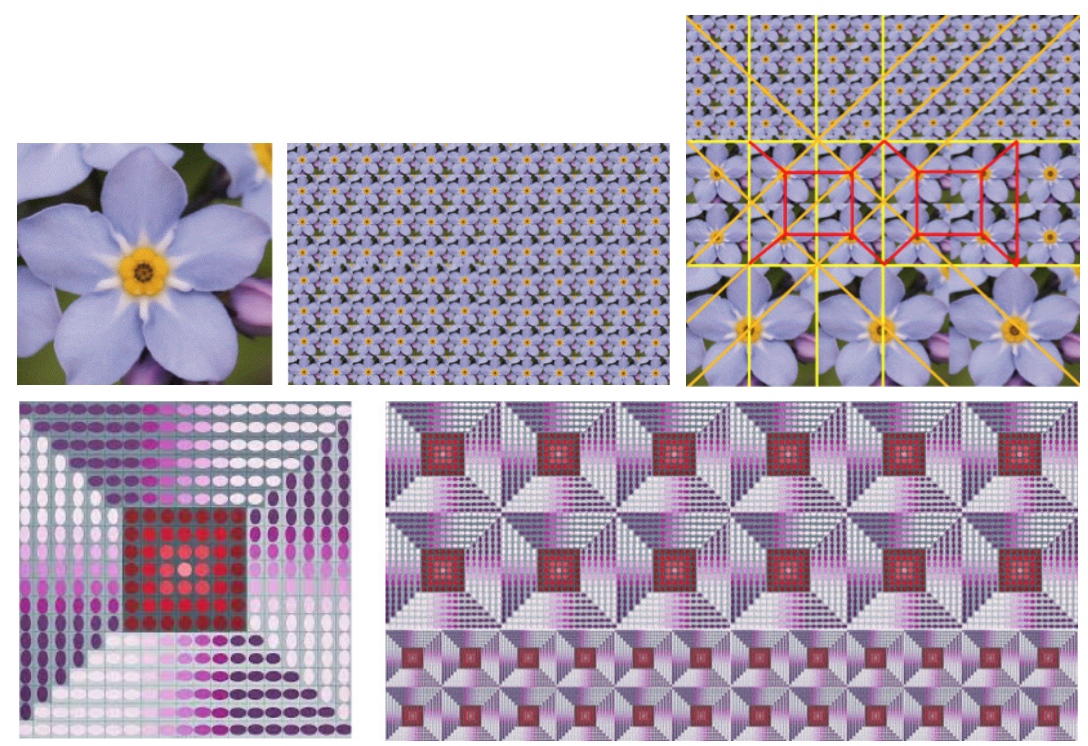


\section{Results and discussion}

Regarding the students' answers to the question in the final examination that was the starting point of the research, the most common mistakes were that many students misconceived the role and nature of the photograph, which was only a visual representation of a natural object and took the composition of the photo comparing it with the painting. Many simply interpret the image in a photo as reality, not the work of a photographer that composes the image he/she wishes. This is a profound question that exceeds the limits of this article. Many students could not see the geometrical structure of compositions, neither in nature nor in art. In these cases, these three worlds have nothing in common for them. Probably these students perceive their study programme as organised following a schema in which the different subjects are entirely separated between themselves even though any study programme has a central nucleus of which they are part.

The partial results of the tests carried out through the first and the second phases of the action research were presented in the article following the explanation of each of them. These results were the departure point for the design of the third (probably the most important and decisive) part of the research. That is why we will not repeat them here; we will rather concentrate on the results of the last phase.

Upon completing the course using transmedia storytelling with interdisciplinary integration between different contents from fine arts, biology and geometry, the students, the teacher and the consultant teachers met to discuss the recent activities and its evaluation and hear the students' opinions on the teaching and learning approach.

The students praised the gradual integration of the introduction of an individual strategy for solving tasks and the possibility of individual choice of fine arts examples. They stated that they were highly motivated by the surprise of the unexpected connections between the contents within the different subjects from the point of view of the general artistic, aesthetic experience. They were also motivated by the use of known concepts in new contexts.

The students' responses showed a strong sympathy for the approach used, mainly because of the possibility that each one can create his/her own solutions for artistic tasks expressing the interests, expectations and performing in their own way.

Students who do not use social media often or are reluctant to do so, because they feel they are constantly exposed to unexpected reactions, stated that the task was not easy. Creating groups with colleagues they knew and in which 
they felt comfortable and safe made them more confident and, in the end, they were amazed by the different paths to which their works led. Nevertheless, they claimed that they had to work on their motivation to feel included in their working groups. This combination of individual and communitarian activities was a great experience for them because it showed them how they could enrich their visions, and the ways in which they could follow a satisfactory process learning more, and in new ways.

Taking into account the different ways in which students learn best, visual, auditory, reading/writing, kinaesthetic and the learning styles regarding the ways in which students deal with their experiences is of primordial importance when designing multimedia didactic material for the class and planning transmedia educational strategies. Transmedia based on interdisciplinary connections requires that the teacher has an excellent knowledge of the contents and objectives of the correlated subjects and that he/she genuinely believes in the possibility of an integrated work within them (Tomšič Amon, 2020, p. 64).

Interdisciplinary integration is a challenge and an opportunity for internal motivation, professional and personal growth for the teacher, as well as a lifelong experience for the students.

The teacher admitted that it was quite strange to work partly in a virtual space where it was not possible to assess and monitor the students. The classroom offers safety. The didactic material is there to be used. Virtual classrooms do not imply such "commodities«. That was why the final evaluation of the achievements developed by the students required a new and specific approach. It required reflection on what and how to evaluate students' work.

Using transmedia visual narratives was the most successful of the three pedagogical strategies compared in this research. It was the most demanding regarding organisation, preparation of study material, assessment of the students, took more time and was the most unpredictable regarding the results. Nevertheless, its results went beyond our expectations and, as it is quite complex, it would be a good strategy to deepen the demands of the given tasks.

\section{Conclusion}

The three phases of our research offered different kinds of data when comparing the strategies used to enhance interdisciplinary, holistic views on the contents we wished students to understand. The first phase gave a somewhat quantitative approach that revealed only raw data and, as such, was not satisfactory. The second phase gave us a general overview of the situation that showed potentials for the third phase's more complex design. Within it, students had 
to synthesise the experiences of both previous phases but also make a huge step showing comprehension of meanings and creative capacities to resolve the proposed problem.

The reality of the task, which required creativity using the discovered data to develop a new product and the conditions of work in group and outside the frames of a traditional class, made a critical difference in the results at the end of the third phase. The fact that each narrative process, if we can, by comparison, call the creative process in this way, grew from the experiences of the students, that teachers did not assess each step but acted only as consultants (so they did not know what students were developing) and the use of social media that facilitated meeting others and also »hiding " and working individually if that was the case was interesting to observe during the whole pedagogic process. The possibility to perform an individual learning strategy with a clear creative applicative end was the main cause of the satisfactory results, remarked this by teachers and students. This is an added value given by the use of transmedia strategies.

On the other side, it must be said that such a learning process is very difficult to assess and, in the end, evaluate. The evaluation of such learning strategies should be the next issue for further research. Another question that opens is whether this kind of work is appropriate for different subjects and schooling levels.

Understanding how art follows nature is a primary objective within the education of future teachers of different subjects, from kindergarten to the university (Arnheim, 1993; Klee, 1968; Munari, 2008). This is a central condition if we wish to educate youth, creating a holistic sense of the world and their lives. Difficulty in connecting information and transferring knowledge, poor abilities to give meaning to images and to understand visual discourse seem to be a persistent problem in many aspects within education at all levels.

The use of digital media and its exponential development creates a world of sharp differences. Probably not so important is the social aspect. Any phone can perform all we need to show our life to others on Instagram. On the other side, there is a generational gap between many teachers confronted with the fact that students possess or know how to access an enormous amount of information facilitated by digital media. Quite often, this information exceeds the contents required within curricula. The contradiction consists of the fact that teachers many times possess less information than the students, who, in contrast, do not possess the tools to manage and classify such information critically. Curricular changes develop at a significantly slower rate than students' need to acquire knowledge and experiences. The acquisition of knowledge through experience that does not present any boundaries or limitations regarding learning contents is an exciting potential to improve this eventually 
conflictive perspective. Probably, this limitless aspect is, at the same time one of the key difficulties teachers face planning their teaching processes.

Multimedia experiences are important not only in the case of art education but for other school subjects. Most of them deal with visual and auditory representations of all kinds. It is not difficult to imagine the meaning of the capacity to imagine spatial relationships in the fields of geometry, geography, biology, physics or chemistry. Complex and refined means of visual and auditory perception and all the meanings this concept involves and supposes are required in almost all activities. Schools at all levels should offer students proper operative experiences and develop specific competencies. At the start of the second decade of the $21^{\text {st }}$ century, there is no doubt about this. In the last three decades or so, the world changed at a rate we could not have imagined. We have no reason to believe that it will be different in the future.

A dialectic view on experience assumes that it is formed based on exchanges between sensory perception and reflection. Experience is not only part of perceptions from the outside world but gets its meaning through interpretative consciousness. Some life experiences (e.g., an aesthetic experience) can transform a person if he/she recognises a particular type of experience in it. With this project, we could vividly come into contact with this aspect of the teaching and learning process.

This work strategy also opens contradictions between different individual experiences, goals and established method to achieve them, the traditional meaning and the mechanisms of motivation and personal commitment in the whole process. It questions the position of each individual promoting self-reflection in order to connect cognitive and emotional aspects with action. We could say that it realises Dewey's (1949) thoughts that when we look at (or create) an artwork, emotions and thinking work together in their perceptible and sensual connection, so experience is the complex in which the world opens and gives us meanings and values also in a non-verbal way.

We can state without a doubt that art education in the $21^{\text {st }}$ century faces new challenges of all kinds. It is necessary to improve experiences using all the possibilities offered by new media because they facilitate the development of spatial visualisation and operations with complex shapes that practically cannot be realised in the traditional way with paper and pencil; they save time and give the possibility of many variants on the same theme very easily. However, it is obvious that the pedagogical process of art education demands the inclusion of a specific way of accurate evaluation of three dimensional-haptic activities that would enable students to experience the characteristics of materials, like texture, toughness, temperature, elasticity, flexibility, plasticity, and porosity, 
which are neglected by screen media. The understanding of past and contemporary art products requires a set of complex and rich experiences, which is one of the principal objectives of education at all levels. Transmedia narratives, because of the potential use of different distribution channels, that are not necessarily connected with screen media, offer a wide range of possibilities tying the real and the virtual in specific modes.

This new culture shifts the centre of the educational process from a frontwards relation between teachers and students, with an individual response and engagement from these to a community that is continuously creating and recreating knowledge.

In today's globally connected world, in which it is possible to use different platforms to connect and communicate, learners and teachers are no longer attached to a specific space. In some way, even if it is difficult to imagine, we could say that the classroom, as the material space where teaching, learning, social interchanges, and similar take place is changing. The learning community is, in fact, a global, multicultural community that eventually uses many verbal languages and scripts and does not need a three-dimensional space to live. In these contexts, visual language becomes a universal that should be widely understood, carrying at the same time the particular touch of cultural peculiarities (Brushwood, 2017).

Without a doubt, new special ways of organisation will be readily required from the teachers and the students. Flexibility in planning and evaluating the results of the work and responsibility and interest for novelties from the part of the students will become unavoidable. Our ideas about what we expect from the learning process should also be attuned. Dialectics among successive experiences that involve teachers with their own experience, professionalism, organisational skills, knowledge, and intuition for individual leadership, and the student who interprets and builds a picture of the world is derived from the way each one accepts the world and assembles elements into a new whole with meaning in a particular, renewed context each time.

The meaning of this research should be seen in an extensive and, at the same time, quite eclectic context: major changes in the perception and evaluation of events in the world of arts, which come about at the same time as large changes in the school environment, rapid functional changes in the lives of teachers, students and our society in general, and a school that will not be the building the elders remember with attachment and emotion but a virtual cloud, somewhere in the universe. 


\section{References}

Arnheim, R. (1993). Consideraciones sobre la educación artística [Considerations on art education]. Paidós.

Brushwood, R. C. (2017). Making emotional and social significance: Digital storytelling and the cultivation of creative influence. In M. Dunford \& T. Jenkins (Eds.), Digital storytelling (pp. 185-202).

York University. https://doi.org/10.1057/978-1-137-59152-4_15

Catmull, E., \& Wallace, A. (2014). Creativity, Inc.: Overcoming the unseen forces that stand in the way of true inspiration. Transworld Digital.

Crary, J. (1992). Techniques of the observer: On vision and modernity in the nineteenth century. The MIT Press.

Critchlow, K. (2011). The hidden geometry of flowers. Floris Books.

Dewey, J. (1949). El arte como experiencia [Art as an experience]. Fondo de cultura económica.

Drake, S. M. (1998). Creating integrated curriculum: Proven ways to increase student learning. Corwin Press.

Eisner, E. W. (2002). The arts and the creation of mind. Yale University Press.

Erickson, H. L. (1995). Stirring the head, heart, and soul: Redefining curriculum and instruction.

Corwin Press.

Gardner, H. (1993). Frames of mind, the theory of multiple intelligences. Fontana Press.

Gray, P. (2000). A problem-solving perspective on knowledge management practices.

http://www.business.queensu.ca/kbe

Jenkins, H. (2006). Convergence culture, where old and new media collide. New York University Press.

Jenkins, H. (2010). Transmedia storytelling and entertainment: An annotated syllabus. Journal of

Media \& Cultural Studies, 24(6), 943-958.

Kalinov, K. (2017). Transmedia narratives: Definition and social transformations in the consumption of media content in the globalised world. Postmodernism problems, $7(1), 60-68$.

Kincheloe, J. L. (2008). Knowledge and critical pedagogy. Springer.

Klee, F. (Ed.) (1968). The diaries of Paul Klee 1898-1918. University of California Press.

Kroeber, K. (2006). Make believe in film and fiction. Palgrave Macmillan.

Lankow, J., Ritchie, J., \& Crooks, R. (2012). Infographics: The power of visual storytelling. John Wiley \& Sons.

Meier, S. L., Hovde, R. L., \& Meier, R. L. (1996). Problem solving: Teachers perceptions, content area models and interdisciplinary connections. School Science and Mathematics, 96(5), 230-237.

Moss, D. M., Osborn, T. A., \& Kaufman, D. (Eds.) (2008). Interdisciplinary education in the age of assessment. Routledge.

Munari, B. (2008). Design as Art. Penguin Books.

Pratten, R. (2015). Getting started with transmedia storytelling: A practical guide for beginners.

CreateSpace Independent Publishing Platform.

Brown, S., \& J., Duguid, P. (2000). The social life of information. Harvard Business School. 
Shannon, D., \& Galle, J. (Eds.). Interdisciplinary approaches to pedagogy and place-based education, from abstract to the quotidian. Rowman and Littlefield.

Thomas, K. (2019). The paradox of creativity in art education: Bourdieu and socio-cultural practice. Palgrave \& Macmillan.

Tomšič Amon, B. (2020). Transmedia narratives in education: The potentials of multisensory emotional arousal in teaching and learning contexts. In B. Peña Acuña (Ed.), Narrative transmedia (pp. 43-70). IntechOpen.

Vimal, R. L. P. (2019). Attention and emotion. Annual Review of Biomedical Sciences, 10.

https://doi.org/10.5016/1806-8774.2008.v10p84

Wilson, M. E. (2004). Teaching, learning, and millennial students. New directions for student services, 106, 95-71. https://doi.org/10.1002/ss.125

Wright, R. D., \& Ward, L. M. (2008). Orienting of Attention. Oxford University Press.

Wurdinger, S. (2017). Turning Your place into projects. In D. Shannon \& J. Galle, (Eds.),

Interdisciplinary approaches to pedagogy and place-based education, from abstract to the quotidian (pp. 37-54). Palgrave \& Macmillan.

Yiend, J. (2010). The effects of emotion on attention: A review of attentional processing of emotional information. Cognition \& Emotion, 24(1), 3-47. https://doi.org/10.1080/02699930903205698

\section{Biographical note}

BEA Tomšič Amon, PhD, is associate professor in the field of didactics of art education at the Department of art education at the Faculty of Education, University in Ljubljana, Slovenia. Her main areas of research are visual arts education, pedagogy of architecture, spatial perception, theory of architecture, geometry and arts, experiential learning and space design. 